\title{
Modifications of the Giant Order in the Leningrad Post-Avant-garde Architecture
}

\author{
Boris M. Kirikov ${ }^{1, *}$ Margarita S. Stieglitz ${ }^{2, a}$ \\ ${ }^{1}$ Leading Researcher, Ph. D. in Art Studies, Central Research and Project Institute, Branch of the FSBI of the \\ Ministry of Construction of Russia Research Institute of Theory and History of Architecture and City Planning, \\ St. Petersburg, Russian Federation \\ ${ }^{2}$ Chief Researcher, Ph. D. in Architecture, Central Research and Project Institute, Branch of the FSBI of the \\ Ministry of Construction of Russia Research Institute of Theory and History of Architecture and City Planning, \\ St. Petersburg, Russian Federation \\ ${ }^{a}$ Email: mstig@mail.ru \\ *Corresponding author. Email: mstig@mail.ru
}

\begin{abstract}
In the present article the authors for the first time reveal the main circle of buildings of the post-avant-garde period that use the giant order. Through comparative analysis, the authors have determined the modifications of the giant order and revealed the specific features of the Leningrad architectural school. The study of this topic is expected to contribute to the preservation of the architectural heritage of Leningrad - St. Petersburg.
\end{abstract}

Keywords: Post-avan-tgarde, Transformed order, Modernized Neo-Classic of 1930-s. Leningrad architectural school, Classical tradition.

\section{INTRODUCTION}

In the early 1930s, there was a sharp turn in Soviet architecture from the cardinal innovations of the avant-garde to the development of the classical heritage. Politics of the Soviet leaders and public demands led to the creation of a certain monumental and representative style, the prototypes of which could be found in the classic. There was no alternative path under the totalitarian regime [1]. The avant-garde was ostracized, but it did not immediately give place to the new trend, producing a hybrid post-avant-garde in the shapes of Art Deco. The modernized Neoclassic took the leading positions. In Leningrad, that direction was of particular importance, because it connected modernity with the great traditions of the Petersburg's Classicism, as well as with the recent search in the frames of the Neoclassic of 1910 early 1920s.

Most of the Leningrad architects of the 1930s

*Fund: This study is based on the research, supported by the Program of Fundamental Research of the Russian Academy of Architecture and Construction Sciences and of the Ministry of Construction, Housing and Utilities of the Russian Federation 2021. gave preference not to retrospective stylization, but to a fundamental reconsidering and renewal of historical forms. It was embodied in the generalization and exaggeration of Classicist schemes and elements. The central theme was the transformed giant order covering several floors or the entire volume of the building. Thus, the impression of monumental might and monolithic unity of the composition was achieved.

The ideological platform of the Leningrad architectural school was the concept of 'proletarian classics', and then - that one of the 'reconstruction of classics' developed by I.A. Fomin in the 1920s. From the formal point of view, his method proceeded from the simplification and purification of the order system, when only a bare skeleton of the order remained. An original innovation of Fomin was paired semi-columns - thin cylindrical pillars without bases and capitals, joined into a single group. Such expedient helped to solve the problem of the giant order, avoiding an excessive elongation or, conversely, a massive of single columns [2]. Another leader of the Leningrad Neoclassicism, V. A. Shchuko, in his works of the 1920s, executed together with V. G. Gelfreikh, used 
other types of vertical elements: simple wide lesenes or high pylons of rectangular cross-section.

One of the most influential architects of that period, N. A. Trotsky, declared later: "In Leningrad, there is... a tendency to go from Fomin and Shchuko. This note is simple and strong" [3]. Along with that important source of the modernized Neoclassicism of the 1930s, a work by German architect P. Berens stays in line; i.e., the building of the German Embassy built according his design in the centre of St. Petersburg in 1911-1913 ("Figure $1 ")$.

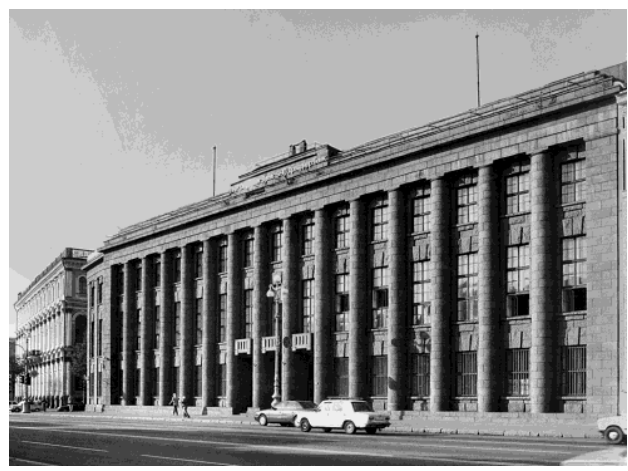

Figure 1 P. Berens. Building of the German Embassy.

The leitmotif of this composition is a mighty modified order of three-quarter columns; it acquired the role of an actual sample existing before everyone's eyes [4].

\section{TRANSFORMATION OF THE COLUMN ORDER}

Large-scale order compositions with a metric arrangement of three-quarter columns were widespread in the Leningrad architecture of the 1930s. Lapidary geometric forms of the giant order were in demand mainly in construction of monumental public buildings. Elongated bodies of columns with a general cross-section, without entasis and usually without bases, were often crowned with simple capitals of the abacus type. Variations of the giant order were based on the methods by P. Berens and I. A. Fomin, which had certain kinship. Moreover, paired high columns were introduced into the architectural lexicon exactly by Fomin.

1. Here and later, in all cases, we mention the initial function of buildings (it can be changed numerously in the following years).
Following the composition of the German Embassy building was a distinctive feature of the Leningrad architectural school. That version of the Neoclassicism was defined by its contemporaries as 'Berensianism'. It was manifested the most clearly in the works by D. P. Buryshkin [5].

Among the earliest and the most illustrative examples of 'Berensianism', we should mention the building of the 'Pravda' Newspaper in the Kherson Street (1933-1934). In its composition, Buryshkin reproduced the main theme of the Berens's design: an embossed system of three-quarter columns closed with antes from the sides. At that, he refused from capitals, simplifying the order even more than Berens ("Figure 2").

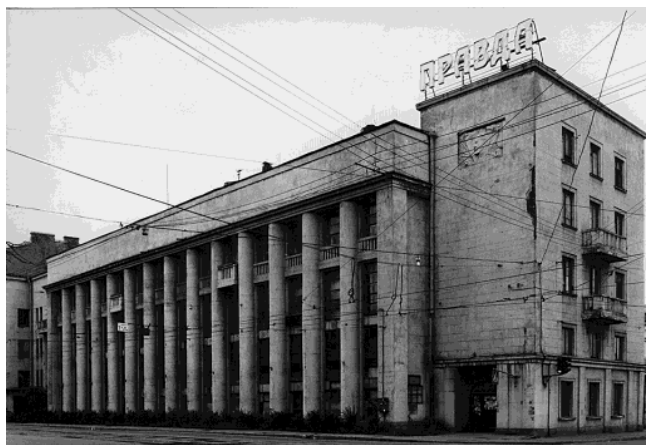

Figure 2 D. P. Buryshkin. Building of the 'Pravda' Newspaper.

In the same style, in 1935-1938, Buryshkin created a whole ensemble on the embankment of the Neva (Malookhtinsky Prospekt). Two large educational buildings, flanking a broad square, are united with a refrain of the giant order. The colonnade of the German Embassy is here as if doubled on the elongated façades because of the bigger quantity of their columns; on the side of the square, dense rows of pillars remind also the design by Berens. Buryshkin also repeated the design of balconies, but located them on another level.

Some Berensian motifs are obvious in nonimplemented projects by Buryshkin, as well. Formulas of the German architect were actively acquired by N. A. Trotsky, I. G. Langbard, M. I. Kitner, and other architects. Though, perhaps, on some ideological reasons, Trotsky repudiated the label of Berensianism, attached him by his contemporaries. Meanwhile, it is evident, that the version of colonnade in his design project of a standard school (1935) could be traced back to the building of the German Embassy.

Under the supervision of Trorsky, the grandiose House of Soviets was erected in the Moskovsky 
Prospekt (1936-1941); it was the apotheosis of the monumental style, a heroic symbol of the epoch ("Figure 3").

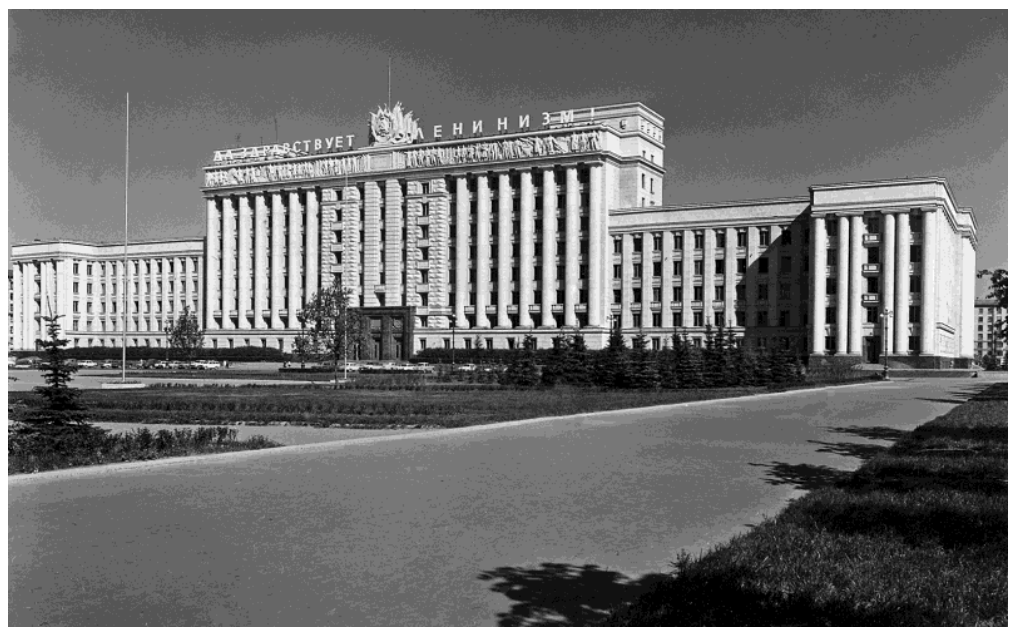

Figure 3 N. A. Trotsky. The House of Soviets.

The building was supposed to become the ceremonial nucleus and the dominant of the new centre of Socialist Leningrad. The basis of its expressive image is an exaggerated order, referring to the methods of both P. Berens and I. A. Fomin. The middle elevated volume is organized with groups of three-quarter columns seven stories high. The flanks of the main façade and the semicircular projection of the assembly hall are highlighted with paired columns.

The theme of paired columns of the cylindrical cross-section, inspired with ideas of I. A. Fomin, dominates in the design of several buildings. On the façades of the Academy of Light Industry in Suvorovsky Prospekt, built in $1934-1937$ by A. P.
Velikanov, L. M. Polyakov and A. F. Khryakov, order elements of this type are raised to the ground floor, according to a long-standing tradition. The compact volume of the Krasnogvardeisky Department Store on Lenin Square, designed by Ya. O. Rubanchik and started with construction works in 1935-1940, is encircled with paired columns. The entire façade has been transformed into a whole order composition. In 1934-1938, at the intersection of Moskovsky Prospekt and Obvodny Canal, the Frunzensky Department Store was erected under the supervision of E. I. Katonin. Its convex body, located along the canal, is also united with the rhythm of paired columns carrying the entablure and attic [6] ("Figure 4").

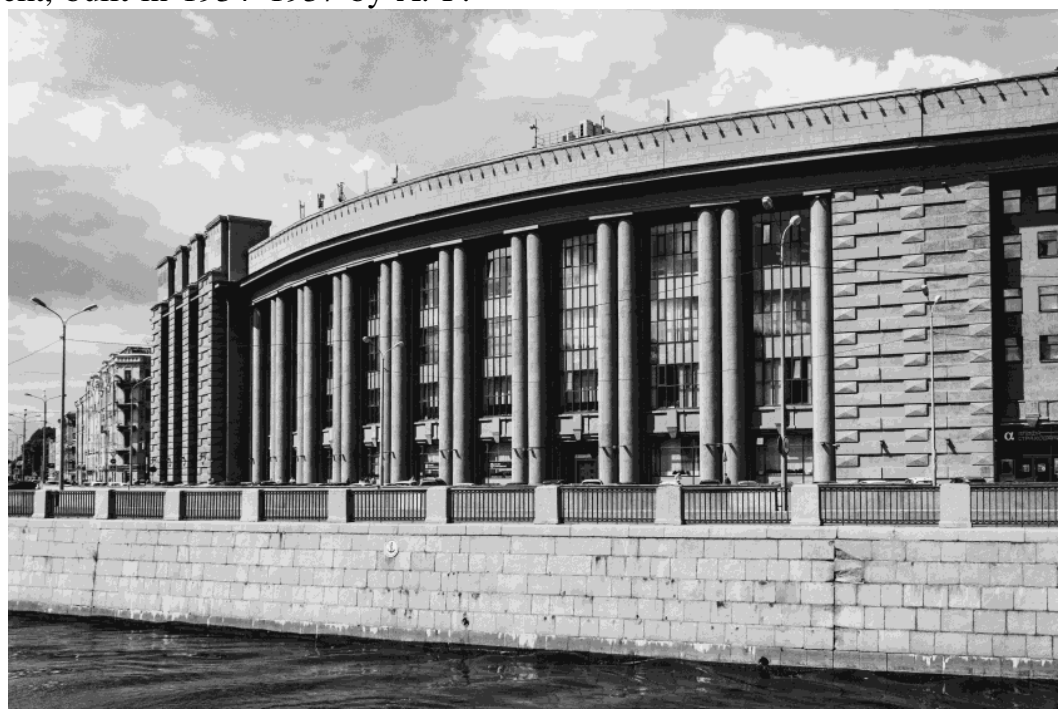

Figure 4 E. A. Katonin (project leader). The Frunzensky Department Store. 
Noteworthy, those buildings did not literally follow the radical innovations by I. A. Fomin. In his works of 1925-1930, paired columns, growing from the ground, cleared of bases and capitals, were completely freed from the entablature. Leningrad architects of the 1930s usually kept those traditional elements, and a pair of columns was not melted into single form but separated inside with a slit-like gap. The plastic of the giant order stood out more prominently in contrast to the glazed intercolumnia. The schematic shapes of columns with capitals and entablature and dark cement plaster strengthened the austere monumentality of the composition, that also evoked associations with the granite façade of the German Embassy.

\section{MODIFICATIONS OF ORDER SCHEMES (WITH PYLONS AND LESENES)}

Beside the transformed colonnades, various types of pylons and lesenes were actively used in the modernized Leningrad Neoclassicism. The development of those vertical elements was carried out in two directions. A tendency towards generalization and schematization was expressed in extremely simplified, rather geometric forms. An alternative to that brutal and lapidary version included more complicated, detailed variants of the giant order. Faceted, profiled pylons and lesenes combined monumental representation and decorative lightness. If the first version of modification of the order schemes in its rigorous austerity went together with avant-garde, the second trend definitely passed into Art Deco.

A key milestone in the architecture of the 1930s was the so called 'Big House', a large building of the NRVD (KGB) in Liteiny Prospekt. Its construction in 1931-1932 was carried out by a group of architects; the author of the design of the façades was N. A. Trotsky. On his own words, the building was "...one of the first monuments of a new trend, based on classic forms" [7]. Its corner volumes remind Constructivism, but the main block on a broad stylobate was made as a compact metric system of giant pylons (or lesenes) enclosed in a huge granite frame. Gigantomania manifested the indestructible power of that bastion of socialism, which has turned into an ominous symbol of the totalitarian epoch.

Principles of Constructivism were laid down by Trotsky as the basis for the project of the Vasileostrovsky Palace of Culture - the largest one in Leningrad; but during its construction (1931-
1937) the composition acquired the features of Classicist monumentality. The leitmotif of the façade was a clear rhythm of the pylon-lesenes.

A simplified variant of the giant order was numerously presented in the works by A. I. Gegello, one of the co-authors of the 'Big House' project. He found an original version of that theme in the early Constructivist monument: the Palace of Culture on Stachek Square (1925-1927, together with D. L. Krichevsky). Its convex glazed centre of the façade was cut with faceted pylons-ribs set with an acute angle forward. A decade later, A. I. Gegello and S. V. Vasilkovsky added a porticologgia to the Constructivist building of baths by architect N. F. Demkov in Chkalovsky Prospekt. The pylon portico was lined with vertical and horizontal grooves, emphasizing the decorative and light image of its forms. An interpretation of order elements in the Gegello's repertoire is characterized with freedom and variety.

The pylon composition was developed in the buildings by L. M. Hidekel, one of the founders of architectural Suprematism [8]. In the building of the Law Institute in Malookhtinsky Prospekt, designed by him in the 1930s, a continuous pylonade runs in the same plane as the side walls. Square pillars, thinning at the top, are complemented with decorative touches - like broken cornices. A row of pylons, enclosed in a huge horizontal frame, is another parallel with the building of the German Embassy, especially since they have an equal number of vertical elements ("Figure 5").

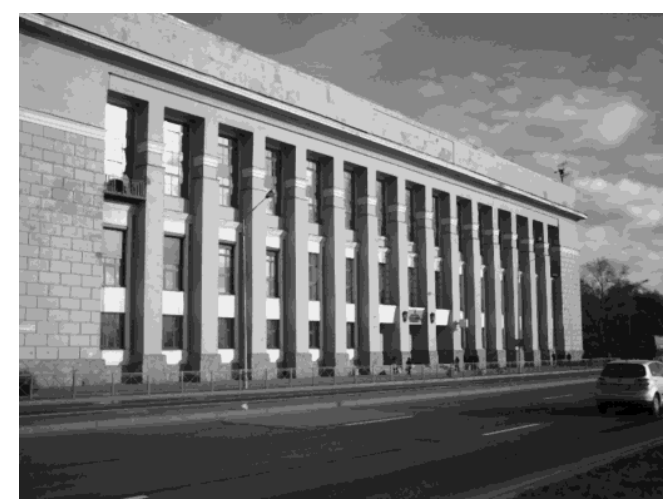

Figure 5 L. M. Hidekel. Building of the Law Institute.

Another version of this theme is presented by L. M. Hidekel in the building of the 'Moscow' Cinema inn Staro-Peterhofsky Prospekt (1937-1939). The first three-hall cinema-theatre in the country had the most compact $\mathrm{T}$-shaped configuration with a 
common foyer. The geometry of the order structure corresponds to the Suprematist geometry of the space-planning structure. In the centre of the façade, there is a modified portico-loggia with double pylons and antes. The elementary simplicity of its forms is compensated with facing with granite rustication, which sets off the representativeness of the entrance zone. The corner parts are broken with open pylon loggias. The constructive meaning of the order is expressed in the monumental composition: vertical supports of its massive attic, on which a multi-figured thematic frieze is placed.

A vertically developed six-pillar portico serves as a striking accent of the façade of the Firefighters Technical School in Moskovsky Prospekt (19361938). Noteworthy, that the authors of the building, L. Yu. Galperin and A. I. Knyazev, introduced pylons instead of the originally designed columns, which seemed too elongated to the construction managers. Light proportions of square pillars enhance the upward orientation of the portico, which is extinguished with a closed attic. Rows of pilasters diverging on the sides also cover all five storeys. Simple capitals and profiled cornice complement the laconic interpretation of the order with references to traditional forms.

A special type of the giant order was represented with simplified fluted pilasters, or, more precisely, lesenes that had neither bases nor capitals. The massive image of those vertical elements was ensured with their large width, one and the same over the entire height.

L. V. Rudnev and Ya. O. Svirsky were the first architects in the construction practice of Leningrad who used such type of order in 1929-1931, in the course of their work over the Textile Institute in Bolshaya Morskaya Street. Here, lesenes penetrate all three façades from top to bottom, from the squat plinth to the schematic entablature. Flutes multiply the number of vertical lines, giving the building a graphic image. The enlarged scale of lesenes emphasizes the heavy mighty form of the bulky structure; and their stable metric rhythm stresses the unity of façades, turning into an excessive monotony of the compositional structure.

On a smaller scale, similar elements were used by L. M. Hidekel in the new building of the
Institute of Civil Engineers in 3rd Krasnoarmeyskaya Street (1932-1934). Triple fluted lesenes flank the middle of this building.

Another variation of the theme was developed by N. A. Trotsky in the development of the concave part of Stachek Square (1934-1936). Paired fluted lesenes, linking several floors, reveal a varied rhythm of the façades. The inclusion of the modified order in the composition of residential buildings increased their role in the space of the square near the triumphal Narva Gates.

A strict rhythm of verticals carrying the entablature defines the outlook of a school building in Gorokhovaya Street built by L. M. Hidekel in 1937-1940. The intricately profiled piers are transformed into a hybrid of pylons and lesenes. A peculiar idea of Hidekel testifies his search for a more detailed form. Thin profiling penetrates the entire height of the façade with light sliding lines; a stepped section of pylons shapes a corrugated surface saturates with a play of light and shade.

The most original variant of the giant order was created by E. A. Levinson and I. I. Fomin (a son of I. A. Fomin). In collective works by that brilliant creative tandem there was an organic balance of monumentality and grace, gigantomania and lightness of forms. The main element of their constructions was faceted pylons elongated to the top and modeled in sophisticated way [9].

A completed example of the individual style of Levinson and Fomin was a dwelling house of the Navy Narkomat on Petrovskaya Embankment. A large building made in 1938-1940 passed through a peculiar metamorphosis: from a skeleton Constructivist hotel to a residential building in the style of modernized Neoclassicism. Its main façade was arranged according the scheme popular in the Leningrad architecture of those years - a row of giant pylons enclosed with antes and the entablature. Pylons of curvy cross-section have concave facets; elongated in the height of six storeys, they do not seem heavy. Miniature porticos of the sixth floor add a soft intimate touch to the ceremonial composition. The hypertrophied scale and strong plasticity of the façade were designed for a distant look from the Neva space ("Figure 6"). 


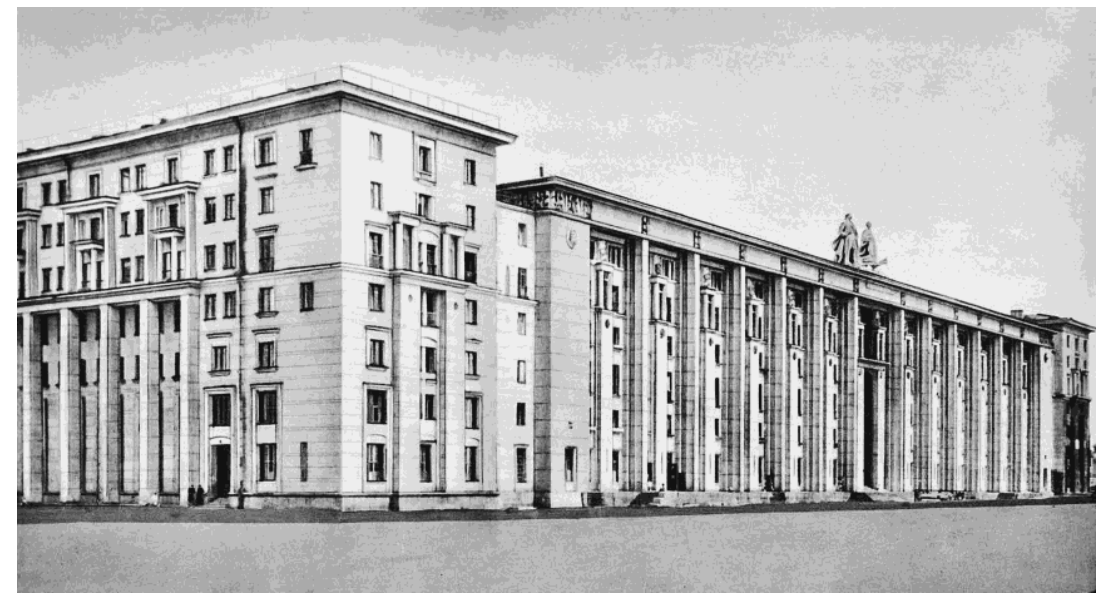

Figure 6 E. A. Levinson, I. I. Fomin. Residential house of the Navy Narkomat.

The building of the Nevsky District Council, designed by Levinson and Fomin in the southeastern part of the city in 1936-1939, is also oriented to the Neva. In its case, an austere row of verticals was reinforced with double faceted pillars of porticos. In the ensemble of residential buildings of the nearby Ivanovskaya Street (1937-1940) the architects inserted some specific plastic accents: two-tier groups of pylons defining a large rhythm of the composition. The authors showed their sophisticated artistic mastership in varying shapes of pylons with concave facets. Particularly impressive are porticos with a convex entablature. The refined decorative image of the façades made the ensemble a paragon of the Leningrad Art Deco.

Innovations by Levinson and Fomin in the field of order were developed in a number of buildings of the late 1930s. Among the best of them was the building of the Pulp and Paper College in Lesnoy Prospekt started on the base of a project by G. A. Simonov in 1938. A giant portico of profiled pylons was superimposed on the main volume of the construction. The upper storeys were decorates with a small order of a more traditional type. (The building was demolished in 2020).

\section{CONCLUSION}

The modernized Neoclassicism was the pivotal direction of the Leningrad architecture of the 1930s. Leading architects creatively reconsidered the traditional order system, modified compositional schemes and typology of forms. The general formula was a simplified giant order, which endowed buildings with heightened monumentality, consonant with the spirit of the epoch.
The methods of updating, transforming the Classicist lexicon were followed by the recent leaders of the avant-garde A.I. Gegello, G.A. Simonov, L.M. Hidekel, N.A.Trotsky, E.A. Levinson, I.I. Fomin. At the same time, some architects, in particular A.A. Ol, D.F. Fridman, V.P. Makashov, were inclined to a retrospective version of Neoclassicism, close to historical prototypes. However, in the 1930s, that line remained in the background.

The specific of the Leningrad architecture of that time was manifested in the brightest form in the new modification of the order. The generalized column order, shaped in the methods by P. Berens and I. A. Fomin, was attractive, first of all, for, D. P. Buryshkin and N. A. Trotsky. Compositions based on pylons (lesenes) were implemented in various variants. Lapidary geomantic forms were typical for some projects by N. A. Trotsky and L. M. Hidekel. More refined and elegant version of pylon structures, close to Art Deco, was developed by E. A. Levinson and I. I. Fomin.

Speaking about the originality of the Leningrad school of the 1930s, we should take into account some obvious stylistic parallels with foreign architecture of that epoch [6], 10]. However, this important aspect of the theme is beyond the frames of the current publication.

\section{AUTHORS' CONTRIBUTIONS}

The authors have been developing the topic for many years. In the period of their work at the Committee for Protection of Monuments of St. Petersburg, B. Kirikov and M. Stieglitz included a number of buildings into the list of such objects protected by the state. The authors also were the 
first who defined the typology of the giant order in the Leningrad architecture of the 1930s.

\section{REFERENCES}

[1] Tarkhanov Alexei \& Kavtaradze Sergei. Stalinist Architecture. London: Laurence King, 1992.

[2] Lisovsky V. G. Ivan Fomin i metamorfozy russkoi neoklassiki (Ivan Fomin and Metamorphosis of Russian Neo-Classic). St. Petersburg: 'Kolo', 2008, p. 380-386, 394400.

[3] Suzdaleva T. E. N. A. Trotsky. Leningrad: 'Lenizdat', 1991, p. 93.

[4] Khan-Magomedovskie chteniya (The KhanMagomedov's Proceedings) / Edit. I. A. Bondarenko. Moscow-St. Petersburg: 'Kolo', 2015, p. 286-292.

[5] Zodchie Sankt-Peterburga. XX vek (Architects of St. Petersbutg. The Twentieth Century) / Comp. V. G. Isachenko. St. Petersburg: 'Lenizdat', 2000, p. 168-191.

[6] Kirikov B. M. Arkhitektura PeterburgaLeningrada: stranitsy istorii (Architecture of Petersburg-Leningrad: Pages of History). St. Petersburg: 'Kolo', 2014, p. 303-309.

[7] Mastera sovetskoi arkhitektury ob arkhitekture (Masters of Soviet Architecture on Architecture), in 2 vol. Vol. 2 / Comp. M. G. Barkhin \& Yu. S. Yaralov. Moscow: 'Iskusstvo', 1975, p. 397.

[8] Lasar Chidekel and Suprematizm. München, London, New York: 'Prestel', 2014, S. 49-59.

[9] Ol G. A., Levinson E. E. Eugene Levinson. Leningrad: 'Striisdat', 1976.

[10] Kirikov B. M. Arkhitektura PeterburgaLeningrada: stranitsy istorii (Architecture of Petersburg-Leningrad: Pages of History). St. Petersburg: 'Kolo', 2014, p. 303-309.

[11] Barkhin A. Ar-deko i stilevoi parallelism v arkhitekture 1930-h (Art Deco and Stylistic Parallelism in Architecture of the 1930-s) // Proekt Baikal. 2019. \# 62, p. 102-107. 